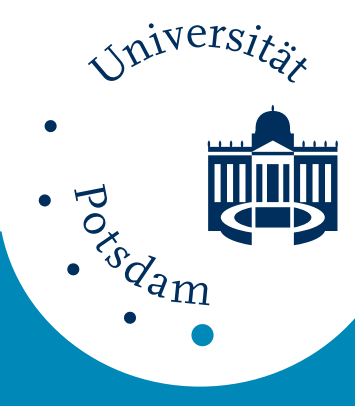

Universität Potsdam

Hans-Jorg Ferenz, Martin G. Peter, Dieter Berg

\title{
Inhibition of farnesoic acid methyltransferase by sinefungin
}

first published in:

Agricultural and biological chemistry. - 50 (1986), 4, pp. 1003-1008

ISSN (online) 1881-1280

ISSN (print) 0002-1369

Postprint published at the Institutional Repository of the

Potsdam University:

In: Postprints der Universität Potsdam :

Mathematisch-Naturwissenschaftliche Reihe ; 77

http://opus.kobv.de/ubp/volltexte/2008/1701/

http://nbn-resolving.de/urn:nbn:de:kobv:517-opus-17016

Postprints der Universität Potsdam

Mathematisch-Naturwissenschaftliche Reihe ; 77

ISSN 1866-8372 


\title{
Inhibition of Farnesoic Acid Methyltransferase by Sinefungin
}

\author{
Hans-Jörg Ferenz, Martin G. Peter* and Dieter BerG** \\ Fachbereich Biologie, Universität Oldenburg, \\ Postfach 2503, D-2900 Oldenburg, F.R.G. \\ * Institut für Organische Chemie und Biochemie der Universität Bonn, \\ Gerhard-Domagk-Str. 1, D-5300 Bonn, F.R.G. \\ ** Bayer AG, Sektor Landwirtschaft, Chemische Forschung, \\ Pflanzenschutzzentrum Monheim, Alfred-Nobel-Str. 50, \\ D-5090 Leverkusen, Bayerwerk, F.R.G.
}

\begin{abstract}
Sinefungin inhibited the S-adenosylmethionine-dependent farnesoic acid methyltransferase in a cell-free system containing a homogenate of corpora allata from female locusts, Locusta migratoria. The enzyme catalyzed the penultimate step of juvenile hormone biosynthesis in the insects. Culturing corpora allata in the presence of sinefungin greatly suppressed juvenile hormone production. The following in vivo effects were visible after injection of the inhibitor: increase in mortality and reduction of total haemolymph protein titer and ovary fresh weight, as well as length of terminal oocytes. Attempts to reverse these effects by topical application of the juvenile hormone analog ZR-515 (methoprene) were only partly successful. Therefore, the in vivo effects may be due to a general inhibition of methyltransferase enzymes in the insect. Sinefungin appeared to be of potential interest as the first representative of a new class of insect growth regulators.
\end{abstract}

The antibiotic fungal metabolite sinefungin (Fig. 1) is a potent inhibitor of a number of $S$-adenosylmethionine-acceptor methyltransferases such as $t$-RNA- and protein methylases ${ }^{1)}$ as well as cyclopropane fatty acid synthetase $^{2)}$ and histamine- $N$-methyltransferase. ${ }^{3)}$ $\mathrm{I}_{50^{-}}$-Values are in the range of $10^{-3}$ to $10^{-6} \mathrm{M}$. In some cases, sinefungin is a much stronger inhibitor of methyltransferases than $S$-adenosyl-homocysteine. ${ }^{1)}$ Inhibition of methyltransferases in insects by sinefungin has not been investigated. Of special interest is farnesoic acid methyltransferase, an enzyme that is involved in the last steps of juvenile hormone biosynthesis in insect corpora allata. ${ }^{4}$ It is well established that this reaction consists of the transfer of the methyl group from $S$-adenosylmethionine (Fig. 1) to either farnesoic acid ${ }^{5)}$ or to 10,11-epoxyfarnesoic acid or higher homologues of the latter. ${ }^{6 \sim 8)}$ We now report on the effects of sinefungin on female locusts, Locusta migratoria, in vivo and on the inhibi- tion of juvenile hormone biosynthesis in corpora allata organ cultures as well as on the inhibition of farnesoic acid methyltransferase in a cell-free system.

\section{MATERIALS AND METHODS}

Insects. Locusta migratoria was obtained from the "Insektarium Dr. Frieshammer" (Jaderberg, F.R.G.). They were kept in the laboratory at $30^{\circ} \mathrm{C}$ with a daily photoperiod of $14 \mathrm{hr}$, and fed with fresh grass, wheat shoots, and flaked oats.

Chemicals. Sinefungin was purchased from Sigma or Calbiochem. [Methyl- ${ }^{14} \mathrm{C}$ ]methionine (specific activity 2.2 $\left.\mathrm{GBq} \mathrm{mmol}{ }^{-1}=60.4 \mathrm{mCi} \mathrm{mmol}^{-1}\right)$ was from AmershamBuchler and [methyl $\left.-{ }^{14} \mathrm{C}\right]-S$-adenosyl-methionine (specific activity $2.2 \mathrm{GBq} \mathrm{mmol}{ }^{-1}=59.9 \mathrm{mCi} \mathrm{mmol}^{-1}$ ) was from NEN-Chemicals. $E, E$-methyl farnesoate was prepared by oxidative methylation ${ }^{9)}$ of farnesol (Fluka, mixture of $E, E$ and $Z, E$-isomers) and the ester was subsequently hydrolyzed in $80 \%$ aqueous ethanol $/ 10 \%$ (w/v) $\mathrm{KOH}$. $E, E$ Farnesoic acid was obtained after chromatography of the reaction products on a $3 \times 34 \mathrm{~cm}$ silica gel column which 

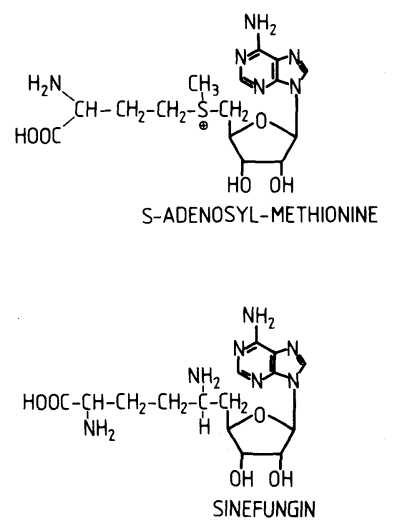

FIG. 1. Structural Formulas of $S$-Adenosylmethionine and Sinefungin.

was eluted with $n$-hexane $/ 10 \%$ ethyl acetate $/ 1 \%$ acetic acid, followed by Kugelrohr distillation. The JH-analog ZR-515 was a gift from Dr. D. Schooley and Dr. S. J. Kramer of Zoecon Corp. to the first author. All glasswares were coated with Carbowax 20M (Serva), by the standard procedure.

In vivo: Experiments. Females of Locusta migratoria were injected two days after emergence with $10 \mu \mathrm{l}$ of a solution containing varying amounts of sinefungin (see Table I) in locust saline,$\left.^{10}\right)$ using a $50-\mu 1$ Hamilton syringe. Five microliters of haemolymph were collected before the injections, and total haemolymph protein was measured by Lowry's method. ${ }^{11)}$ The injections of sinefungin solutions as well as the collection of haemolymph samples were repeated every two days. The animals were dissected on the 15th day after emergence and again haemolymph protein concentration as well as ovary fresh weight and length of terminal oocytes were measured. Some of the sinefungin-injected locusts were given $5 \mu \mathrm{l}$ of a solution of the juvenile hormone analog ZR-515 in acetone $(20 \mathrm{mg}$ $\cdot \mathrm{ml}^{-1}$ ) or acetone alone (topical application) after each injection.

Organ culture of corpora allata. Corpora allata were dissected from $0 \sim 24 \mathrm{hr}$ old adult female locusts, washed in sterile incubation medium, and incubated as described previously. ${ }^{12)}$ To stimulate glands to maximum biosynthetic activity, farnesoic acid was added to the incubation medium to give a final concentration of $0.1 \mathrm{~mm}^{12)}$ The concentration of methionine (radio-labelled plus radioinactive from medium) was adjusted to $0.31 \mathrm{~mm}$. The corpora allata were removed from the culture after $2 \mathrm{hr}$ and the medium was extracted with $300 \mu \mathrm{l}$ of iso-octane. ${ }^{13)}$ Samples of the extract were used for measurement of radioactivity.

Cell-free system. An extract of 50 pairs of corpora allata was prepared as described by Feyereisen et al. ${ }^{14)}$ The glands were homogenized in $300 \mu$ l of ice-cold sodium phosphate buffer $(100 \mathrm{~mm}, \mathrm{pH} 7.0)$ containing $1 \mathrm{~mm}$ EDTA and $1 \mathrm{~mm}$ mercaptoethanol. The homogenate was layered onto $500 \mu \mathrm{l}$ of the phosphate buffer containing $5 \%$ sucrose. After $2 \mathrm{hr}$ of centrifugation at $88,000 \times g$ at $4^{\circ} \mathrm{C}$, $200 \mu \mathrm{l}$ of the top layer of the supernatant were removed, mixed with $200 \mu \mathrm{l}$ of $30 \%$ aqueous glycerol solution, and stored in several batches frozen at $-70^{\circ} \mathrm{C}$. A $10-\mu \mathrm{l}$ sample containing 1.7 gland pair equivalents, was incubated in $90 \mu \mathrm{l}$ of the phosphate buffer to which $0.4 \mu \mathrm{g}(1.6 \mathrm{nmol})$ of farnesoic acid and $0.7 \mu \mathrm{g}$ of [methyl- $\left.{ }^{14} \mathrm{C}\right] S$-adenosylmethionine hydrogensulfate $(1.7 \mathrm{nmol}$, containing $0.1 \mu \mathrm{Ci})$ as well as varying amounts of sinefungin were added. The total volume was consequently $100 \mu \mathrm{l}$. After incubation for $30 \mathrm{~min}$ at $30^{\circ} \mathrm{C}$, the mixture was extracted once with $300 \mu \mathrm{l}$ of iso-octane containing $1.3 \mu \mathrm{g}$ of methyl farnesoate and samples of the iso-octane phase were removed for counting and HPLC-analysis.

Analytical procedures. Radioactivity was measured either in a Packard Prias PL liquid scintillation counter using Instafluor (Packard) as the liquid scintillation cocktail or in a Berthold BF 820 apparatus in Rialuma Cocktail (Baker). Counting efficiency was $85 \sim 92 \%$ for ${ }^{14} \mathrm{C}$ depending on quenching effects as measured by the external standard method. Quench corrections were made by use of an on-line HP 9815 calculator. Centrifugation was done in a Beckman L8 Ultracentrifuge using the Beckman rotor $\mathrm{SW} 55 \mathrm{Ti}$ with adaptors for $0.8 \mathrm{ml}$ centrifugation tubes. HPLCs were done with an apparatus built from Waters components. The column was either $0.4 \times 31 \mathrm{~cm} \mu$ porasil, eluted with $n$-hexane $/ 0.5 \%$ ethyl acetate $/ 0.005 \% 2$ propanol at a flow rate of $1.0 \mathrm{ml} \cdot \mathrm{min}^{-1}$, or $0.4 \times 31 \mathrm{~cm} \mu$ Bondapak connected with a $0.4 \times 3 \mathrm{~cm} \mathrm{C}_{18}$-porasil precolumn which were eluted with a linear gradient solvent system running from $50 \sim 100 \%$ methanol in $\mathrm{H}_{2} \mathrm{O}$ over $60 \mathrm{~min}$ at a flow rate of $1.0 \mathrm{ml} \cdot \mathrm{min}^{-1}$. Compounds were detected by UV-absorption at $235 \mathrm{~nm}$. Fractions of $0.5 \mathrm{ml}$ were collected for observation of radioactivity distributions.

\section{RESULTS}

\section{Effects of sinefungin in vitro}

The production of juvenile hormone $(\mathrm{JH}-$ III) by corpora allata stimulated by farnesoic acid was measured in organ culture. Examination of extracts of the culture medium by thin layer chromatography revealed that the radioactivity from [methyl $\left.{ }^{14} \mathrm{C}\right]$ methionine was incorporated almost exclusively into $\mathrm{JH}$ III. A greatly decreased incorporation of radioactivity into JH-III was apparent already at $0.3 \mathrm{~mm}$ sinefungin and hormone production fell down to background levels of inhibitor 


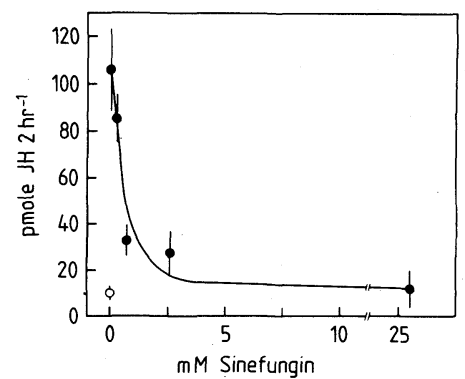

FIG. 2. Inhibition of Juvenile Hormone Biosynthesis by Sinefungin in Organ Cultures of Corpora Allata Pairs of Female Locusta migratoria.

Data points are mean values $\pm \operatorname{SEM}(n=8)$.

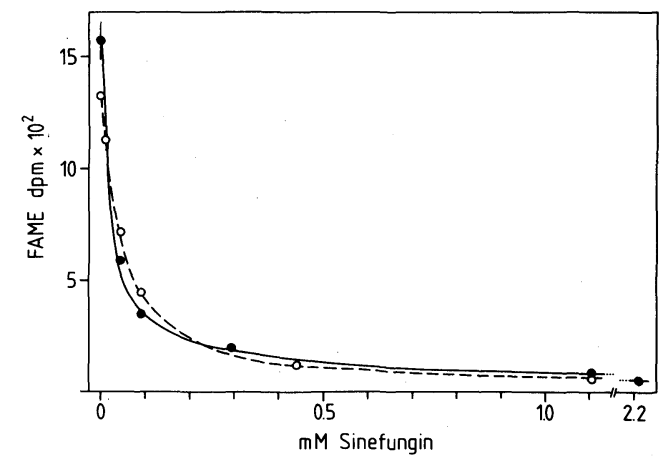

FIG. 3. Inhibition of Farnesoic Acid Methyltransferase in a Cell-free System from Corpora Allata of Female Locusta migratoria.

The concentration of farnesoic acid was $16 \mu \mathrm{M}(\bullet)$ or $32 \mu \mathrm{M}(\mathrm{O})$ respectively. The concentration of [methyl $\left.-{ }^{14} \mathrm{C}\right]-$ $S$-adenosylmethionine was always $16 \mu \mathrm{M}$. Each data point was obtained from five experiments. The SEM is smaller than the diameter of the point in the graph, if not indicated.

concentrations above $3 \mathrm{~mm}$ (Fig. 2).

Further confirmation of the inhibition by sinefungin of the methylation of farnesoic acid from $S$-adenosylmethionine was obtained using a crude methyl-transferase containing an enzyme preparation from corpora allata. Figure 3 shows that there is a strong inhibition of incorporation of radioactivity from [methyl ${ }^{14} \mathrm{C}$ - $S$-adenosylmethionine into products which can be extracted with isooctane. The effect was obvious already at sinefungin concentrations of $0.1 \mathrm{mM}$. Complete inhibition was observed at concentrations of about $0.5 \mathrm{~mm}$. To see whether radio- activity was also incorporated into products other than methylfarnesoate, a sample of the combined extracts from 10 enzyme incubations without sinefungin which contained $152,000 \mathrm{dpm}$ were analyzed by HPLC on a $\mu$ Bondapak column. All of the injected radioactivity $(95,000 \mathrm{dpm})$ were recovered in the eluate. Methylfarnesoate contained $83,800 \mathrm{dpm}$ and the remaining radioactivity was associated with one major and several minor more polar products. The major polar product was eluted shortly behind synthetic JH-III. Similarly, when an extract from 10 incubations of corpora allata with $1.0 \mathrm{~mm}$ sinefungin (contained $2,250 \mathrm{dpm}$ ) was analyzed under the same conditions, more than $95 \%$ of the injected radioactivity was in the peak corresponding to methylfarnesoate.

\section{Effects of sinefungin in vivo}

The observations made after six repeated injections of sinefungin into female locusts are summarized in Table I. An increase in mortality of the insects was only found at rather high doses of the inhibitor. Locusts surviving at such high doses moved and ate much less. Their cuticle had an unusual reddish-brown colour and a paper-like consistency. A dosedependent reduction in ovary weight, oocyte development, and total haemolymph protein were caused by the injection of increasing amounts of sinefungin. Higher doses of sinefungin suppressed any development of the ovaries and the fatbody. Both of the tissues remained in the premature stage of development found right after adult emergence; i.e., the oocytes were very small and the undeveloped fatbody had a whitish colour indicating the absence of reserve materials. After injection of small amounts of sinefungin, the locust ovaries showed a retarded growth and often resorption of partly matured oocytes occurred. Figure 4 shows the correlation between inhibitor dose and total haemolymph protein concentration during adult development. The protein concentration reached a maximum on the 13th day in the control animals. This maximum was apparently sup- 
Table I. Effects ${ }^{a}$ OF Sinefungin on Sexual Maturation during the First GONOTROPHIC CYCLE OF Locusta migratoria

\begin{tabular}{cccccc}
\hline $\begin{array}{c}\text { Sinefungin } \\
\text { injected } \\
(\mu \mathrm{g})\end{array}$ & $\begin{array}{c}\text { Haemolymph } \\
\text { protein } \\
\left(\mathrm{mg} \cdot \mathrm{ml}^{-1}\right)\end{array}$ & $\begin{array}{c}\text { Ovary } \\
\text { weight } \\
(\mathrm{mg})\end{array}$ & $\begin{array}{c}\text { Oocyte } \\
\text { length } \\
(\mathrm{mm})\end{array}$ & $\begin{array}{c}\text { Mortality } \\
(\%)\end{array}$ & $\mathrm{N}$ \\
\hline 0 & $67.7 \pm 3.9$ & $233.3 \pm 33.3$ & $4.3 \pm 0.6$ & 14 & 12 \\
6 & $67.2 \pm 5.2$ & $211.8 \pm 34.0$ & $3.9 \pm 0.3$ & 7 & 14 \\
60 & $59.3 \pm 3.9$ & $100.9 \pm 22.8$ & $2.6 \pm 0.4$ & 13 & 13 \\
150 & $36.9 \pm 2.3$ & $15.6 \pm 1.9$ & $<1.3$ & 9 & 10 \\
300 & $24.3 \pm 4.5$ & $8.3 \pm 1.8$ & $<1.3$ & 75 & 4 \\
\hline
\end{tabular}

a All measurements were made on day 15 after adult emergence. Data are mean values \pm SEM.

$b$ The amounts are the sum of six equal doses applied by repeated injections every second day (see MATERIALS AND MeTHODS).

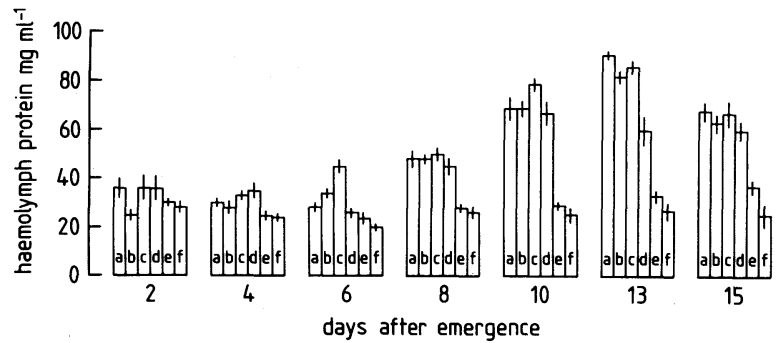

FIG. 4. Concentration of Total Haemolymph Protein in Female Locusta migratoria after Consecutive Injections of Varying Amounts of Sinefungin on 2, 4, 6, 8, 10, and 12 Days after Emergence.

Each bar represents the results of 4 to 15 individual haemolymph samples (mean value \pm SEM). Each measurement was done in duplicate. Dose amounts of sinefungin per injection are a) $0.0 \mu \mathrm{g}, \mathrm{b}) 0.1 \mu \mathrm{g}, \mathrm{c}) 1.0 \mu \mathrm{g}$, d) $10.0 \mu \mathrm{g}$, e) $25.0 \mu \mathrm{g}$, and f) $50.0 \mu \mathrm{g}$.

TABle II. EFfects OF the Juvenile Hormone ANALOG (ZR-515) ON SinEFUNGININJECTED LOCUSTS

\begin{tabular}{|c|c|c|c|}
\hline Treatment ${ }^{a}$ & $\begin{array}{c}\text { Ovary } \\
\text { weight } \\
\text { (mg) }\end{array}$ & $\begin{array}{l}\text { Oocyte } \\
\text { length } \\
(\mathrm{mm})\end{array}$ & $\mathrm{N}$ \\
\hline Saline, acetone & $425.7 \pm 108.0$ & $5.0 \pm 0.3$ & 8 \\
\hline $\begin{array}{l}\text { Saline plus } \\
\qquad 100 \mu \mathrm{g} \text { ZR-515 }\end{array}$ & $605.9 \pm 79.7$ & $5.6 \pm 0.2$ & 9 \\
\hline $\begin{array}{l}200 \mu \mathrm{g} \text { sinefungin, } \\
\text { acetone }\end{array}$ & $52.6 \pm 9.1$ & $<1.3$ & 9 \\
\hline $\begin{array}{l}200 \mu \mathrm{g} \text { sinefungin } \\
\text { plus } 100 \mu \mathrm{g} \text { ZR-515 }\end{array}$ & $65.5 \pm \quad 7.3$ & $<1.3$ & 7 \\
\hline
\end{tabular}

a Sinefungin was injected into the animals, whereas ZR-515 was applied topically as a solution in acetone (see Materials AND METHODS for details).

pressed by sinefungin exceeding $10 \mu \mathrm{g}$ per injection. Although we attempted to restore the process of sexual maturation in sinefungin- injected female locusts by application of high doses of the juvenile hormone analog ZR-515, it was not successful (Table II). However, there were signs for enhancement of fatbody development and increase of haemolymph protein concentration. Occasional inspection of corpora allata revealed that sinefungin-injected animals had rather small glands, reflecting a low biosynthetic activity.

\section{DISCUSSION}

The biosynthesis of juvenile hormone in Locusta migratoria is known to occur by the $S$ adenosylmethionine dependent methylation of farnesoic acid to give methyl farnesoate, which is then oxidized at the terminal double bond to $(10 R)-2 E, 6 E-10,11$-epoxy-3,7,11-trimethyldodecadienoate methyl ester (epoxyfarnesoic acid methyl ester, JH-III). ${ }^{5,14)}$ This sequence of 
steps is reversed in several other insects, such as in the lepidoptera Manduca sexta and Hyalophora cecropia. ${ }^{15)}$ The enzyme from Locusta corpora allata catalyzes the methy1ation both farnesoic acid and 10,11-epoxyfarnesoic acid in vitro.

We observed in preliminary experiments that the epoxyfarnesoic acid methyltransferase from male accessory sex glands of Hyalophora cecropia $^{4,8,15)}$ was inhibited by sinefungin. The amount of enzyme available then was too small to do a more detailed study. This indicated, however, that the effects of sinefungin were interesting enough for us to investigate the inhibitor in another insect, Locusta migratoria, which was available more easily. The results of this study showed that farnesoic acid methyltransferase was inhibited by sinefungin in a cell free enzyme preparation. HPLC analysis of the reaction mixture from an incubation without sinefungin showed that most of the extractable radioactivity was indeed present as methyl farnesoate. The incorporation of [methyl- $\left.{ }^{14} \mathrm{C}\right]-S$-adenosylmethionine into farnesoic acid in the presence of sinefungin decreased drastically with increasing concentrations of the inhibitor. Though the properties of the enzyme have not yet been measured due to the obvious problems in obtaining sufficient amounts for a complete assessment of substrate conversion and inhibition kinetics, it is reasonable to assume that sinefungin acts as a competitive inhibitor of farnesoic acid methyltransferase.

In organ culture of corpora allata, the incorporation of radioactivity from [methyl$\left.{ }^{14} \mathrm{C}\right]$-methionine into juvenile hormone can be used as a measurement of juvenile hormone production $^{16)}$ (see ref. 17 for review and discussion). Strong inhibition of juvenile hormone production was observed in organ culture in the presence of about $1 \mathrm{~mm}$ sinefungin. The inhibition of hormone synthesis may be due to several effects, including disturbance of regulatory processes in enzyme synthesis and transportation phenomena. The observations on farnesoic acid methyltransferase in the cell free system suggest, however, that sinefungin may also act in organ culture to inhibit the same enzyme.

It is presently impossible to argue about the mode of action of sinefungin in vivo. The reduction of ovary fresh weight, as well as of the size of terminal oocytes and fatbody, were similar to those observed after allatectomy at early stages of sexual maturation. ${ }^{18 \sim 20)}$ The decrease in haemolymph protein concentration may be in part attributed to a lack of vitellogenin synthesis which is regulated by juvenile hormone. ${ }^{1821)}$ It was, however, not possible to reverse these effects notably by topical application of the juvenile hormone analog ZR-515. An increase in mortality was found only after 6 injections of $50 \mu \mathrm{g}$ sinefungin, and this dose was five-fold higher than that required for the appearance of the other effects. Though the animals were not lethally affected by small doses of sinefungin, it may be expected that at least the fertility of the females will be severely impaired. Most likely, sinefungin acts in locusts as a generally toxic agent and the inhibition of juvenile hormone biosynthesis may be only one of the reasons for the inhibition of ovarian development. We do believe that the observations reported here on both in vitro and in vivo systems will stimulate further research on a new class of insect growth regulators.

Acknowledgments. We are grateful to Mrs. E. Fischer for excellent technical help. This work was supported by the Deutsche Forschungsgemeinschaft by grants to both of us and by a Heisenberg Fellowship to M.G.P.

\section{REFERENCES}

1) M. Robert-Gero, A. Pierre, M. Vedel, J. Enouf, F. Lawrence, A. Raies and E. Lederer, "Enzyme Inhibitors," ed. by U. Brodbeck, Verlag Chemie, Weinheim, 1980, pp. $61 \sim 74$.

2) D. D. Smith and S. J. Norton, Biochem. Biophys. Res. Commun., 94, 1458 (1980).

3) R. W. Fuller and R. Nagarajan, Biochem Pharmacol., 27, 1981 (1978).

4) G. F. Weirich, Meth. Enzymol., 111, 540 (1985).

5) A. F. Hamnett, G. E. Pratt, K. M. Stott and R. C. Jennings, "Juvenile Hormone Biochemistry," ed. by G. E. Pratt and G. T. Brooks, Elsevier, Amsterdam, 1981, pp. $93 \sim 105$. 
6) D. Reibstein and J. H. Law, Biochem. Biophys. Res. Commun., 55, 266 (1973).

7) G. F. Weirich and M. G. Culver, Arch. Biochem. Biophys., 198, 175 (1979).

8) M. G. Peter, S. Gunawan and H. Emmerich, Experientia, 35, 1141 (1979).

9) E. J. Corey, J. A. Katzenellenbogen, N. W. Gilman, S. A. Roman and B. W. Erickson, J. Am. Chem. Soc., 90, 5618 (1968).

10) W. Mordue and G. L. Goldsworthy, Gen. Comp. Endocrinol., 12, 360 (1969).

11) O. H. Lowry, N. J. Rosebrough, A. L. Farr and R. J. Randall, J. Biol. Chem., 193, 265 (1951).

12) H.-J. Ferenz and I. Diehl, Z. Naturforsch., 38c, 856 (1983)

13) R. Feyereisen and S. S. Tobe, Anal. Biochem., 111, 372 (1981).

14) R. Feyereisen, G. E. Pratt and A. F. Hamnett, Eur. J. Biochem., 118, 231 (1981).
15) M. G. Peter, P. D. Shirk, K. H. Dahm and H. Röller, Z. Naturforsch., 36c, 579 (1981).

16) R. J. Weaver, G. E. Pratt, A. F. Hamnett and R. C. Jennings, Insect Biochem., 10, 245 (1980).

17) S. S. Tobe and R. Feyereisen, "Endocrinology of Insects (Invertebrate Endocrinology)," Vol. 1, ed. by R. G. A. Downer and H. Laufer, Alan R. Liss, New York, 1983, pp. $161 \sim 178$.

18) T. T. Chen, P. Couble, F. L. de Lucca and G. R. Wyatt, "The Juvenile Hormones," ed. by L. I. Gilbert, Plenum Press, New York and London, 1976, pp. $505 \sim 529$.

19) P. Lazarovici and M. P. Pener, Gen. Comp. Endocrinol., 33, 434 (1977).

20) F. Goltzene and A. Porte, Gen. Comp. Endocrinol., 35, 35 (1978).

21) H.-J. Ferenz and I. Kaufner, "Juvenile Hormone Biochemistry," ed. by G. E. Pratt and G. T. Brooks, Elsevier, Amsterdam, 1981, pp. 135 145. 